\title{
Virulence of Blumeria graminis f. sp. tritici on Winter Wheat in the Eastern United States
}

\author{
A. S. Niewoehner, Former Graduate Student; and S. Leath, USDA-ARS and Associate Professor, Department of \\ Plant Pathology, North Carolina State University, Raleigh 27695
}

\begin{abstract}
Niewoehner, A. S., and Leath, S. 1998. Virulence of Blumeria graminis f. sp. tritici on winter wheat in the eastern United States. Plant Dis. 82:64-68.

Samples of perithecia of Blumeria graminis f. sp. tritici from senescing wheat leaves were collected by cooperators from 17 states. Ascospores were discharged from perithecia and singlespore isolates were characterized for virulence genes using a differential host series containing 15 known resistance genes. A total of 520 isolates from 17 states were characterized in 1993 and 1994. Virulence frequencies and complexity and racial composition were examined. The data were analyzed for associations among sets of virulence genes and the geographical distribution of phenotypes. Virulence to $P m 3 c, P m 3 f, p m 5, P m 6$, and $P m 7$ was present in all states surveyed. Since 1990, virulence to $P m 3 a$ has increased in the northeast, and virulence to $P m 1, P m 4 b, P m 8$, and $P m 17$ has increased across the area surveyed. The resistance genes $P m 12$ and Pm16 remain highly effective in the southeastern United States. An increase in virulence frequencies and complexity of isolates was observed.
\end{abstract}

Additional keywords: population genetics, Triticum aestivum

Powdery mildew, caused by Blumeria graminis (DC) E. O. Speer f. sp. tritici Em. Marchal (=Erysiphe graminis f. sp. tritici), is an economically important disease of soft red winter wheat in the eastern United States $(12,17)$. Yield losses ranging up to $34 \%$ have been reported on susceptible cultivars (10). Seed treatments may not be sufficient for season-long control. Foliar fungicides are available, but they may not be economically feasible $(4,5,12,17)$. Resistant cultivars are the primary control method, but plant breeders have relied on single-gene resistance (13). Selection pressure applied by commonly grown cultivars carrying major resistance genes causes virulence shifts in the $B$. graminis f. sp. tritici population. Surveys of $B$. graminis $\mathrm{f}$. sp. tritici virulence frequencies are necessary to identify which resistance genes are ineffective as well as effective aids for resistance breeding. The virulence frequencies to powdery mildew resistance genes have been well-documented for many years in Europe $(7,9,16)$. Only a few localized surveys have been conducted in the United States $(14,18,20,22)$. A largescale survey was needed to determine

Corresponding author: Steven Leath

E-mail: steven_leath@ncsu.edu

Accepted for publication 16 September 1997.

Publication no. D-1997-1028-02R

This article is in the public domain and not copyrightable. It may be freely reprinted with customary crediting of the source. The American Phytopathological Society, 1998. virulence shifts, genetic diversity, independence of virulence genes, and geographic patterns in the $B$. graminis f. sp. tritici population.

Resistance genes in the host play an important role in determining powdery mildew virulence gene frequencies. Consequently, it is important to know the resistance genes present in currently used cultivars. There have been several reviews of the use of powdery mildew resistance genes, and two recent studies have postulated putative resistance genes in cultivars grown in North Carolina and Ohio $(1,3,13,21)$

The objective of this study was to characterize the powdery mildew population using perithecia collected from the eastern United States, and to examine relationships between populations from different geographic areas of this region.

\section{MATERIALS AND METHODS}

Samples of perithecia on dry, senesced wheat leaves were received from 17 states in 1993 and 12 states in 1994. Of the 418 samples received, 89 and 72 samples from 45 and 30 locations were characterized in 1993 and 1994, respectively. Figure 1 shows the locations in the eastern United States from which powdery mildew isolates were obtained.

In order to obtain $B$. graminis f. sp. tritici isolates from the perithecia, ascospore differentiation and release was induced. A $2.5-\mathrm{cm}$ segment was cut from each leaf and mounted on moist filter paper in the lid of a 100 - by $15-\mathrm{mm}$ petri dish. The lid was cleaned with $95 \%$ ethanol for $1 \mathrm{~min}$, and rinsed twice with sterile water.
The base of the petri dish was filled with $50 \mathrm{mg} /$ liter benzimidazole-amended $0.5 \%$ water agar. The plates were placed in a $17^{\circ} \mathrm{C}$ growth chamber with $12 \mathrm{~h}$ of fluorescent light $\left(75 \mu \mathrm{E} \cdot \mathrm{m}^{-2} \cdot \mathrm{s}^{-1}\right)$. The ascospores differentiated and dispersed within 4 to 6 days. Spores were captured on detached leaves of susceptible wheat cultivar, Chancellor, which were added each day to the media underneath mounted perithecia. A limited number of detached leaves fit underneath the mounted perithecia in the petri plate; therefore, after the fourth day, the petri plate lids holding the perithecia were placed over a new sterile plate of benzimidazole-amended agar. Detached wheat leaves were placed on the agar under perithecia for 3 consecutive days. The fungus sporulated on the detached leaves 14 to 18 days after the experiment was begun. Spores were transferred using a paintbrush from a single pustule to fresh detached wheat leaves. The fungus was transferred every 12 to 14 days to new wheat leaves. B. graminis f. sp. tritici isolates from 1993 and 1994 were transferred from singlepustules two and three times, respectively, to insure purity. Chancellor was the universal suscept used in all experiments. Wheat lines were grown in 6- by 6 -cm plastic pots in a commercial potting mix (MetroMix, W. R. Grace \& Co. Cambridge, MA) in a $17^{\circ} \mathrm{C}$ chamber with $12 \mathrm{~h}$ daylight per $24-\mathrm{h}$ period. Spores from the isolates were in-

Table 1. Cultivars and accession numbers of wheat lines used to characterize virulence of Blumeria graminis f. sp. tritici isolates from 17 states in the United States

\begin{tabular}{|c|c|c|}
\hline Cultivar & $\begin{array}{c}\text { Accession } \\
\text { number }\end{array}$ & $\begin{array}{l}\text { Resistance } \\
\text { gene }\end{array}$ \\
\hline Axminster ${ }^{\mathrm{z}}$ & CI14114 & Pml \\
\hline Ulka $^{\mathrm{z}}$ & CI14118 & Pm2 \\
\hline Orestis & None & Pm2 \\
\hline Asosan ${ }^{2}$ & CI14120 & Pm $3 a$ \\
\hline $\mathrm{Chul}^{\mathrm{z}}$ & CI14121 & $P m 3 b$ \\
\hline Sonora ${ }^{\mathrm{z}}$ & CI14122 & $P m 3 c$ \\
\hline Michigan Amber ${ }^{z}$ & CI14033 & $\operatorname{Pm} 3 f$ \\
\hline Yuma & CI14123 & $\mathrm{Pm} 4 a$ \\
\hline Ronos & None & $P m 4 b$ \\
\hline Kormoran & None & $p m 5$ \\
\hline Coker 747 & None & Pm6 \\
\hline Transec & CI14189 & $\operatorname{Pm} 7$ \\
\hline Kavkaz & PI361879 & $\operatorname{Pm} 8$ \\
\hline Pm12 & None & Pm12 \\
\hline Pm16 & None & Pm16 \\
\hline Amigo & CI17609 & Pm17 \\
\hline Chancellor & CI12333 & None \\
\hline
\end{tabular}

${ }_{\mathrm{z}}$ These lines were crossed to Chancellor nine times. 
creased and screened on a differential host series to determine the virulence genes associated with each isolate. The differential host series consisted of wheats containing 15 resistance genes and the universal suscept, Chancellor (Table 1). A 2.5-cm segment was cut from each leaf of the 15 differential hosts and placed on sterile benzimidazole-amended $0.5 \%$ water agar in a $100-$ by $15-\mathrm{mm}$ petri plate. Leaves infected with each isolate were used to inoculate wheat leaves in each petri plate. A miniature settling tower composed of a 0.47 -liter cup with a $1.5-\mathrm{cm}$ opening at the top for insertion of the infected leaf was used to aerially distribute spores to the petri plate below. Plates were placed in a $17^{\circ} \mathrm{C}$ growth chamber with $12 \mathrm{~h}$ of light, and rated after 10 days using an evaluation scale modified from Leath (13), in which 0 = immune, no visible signs or symptoms; 1 $=$ highly resistant, small flecks only; $2=$ resistant, chlorotic flecks evident; $3=$ resistant, large flecks with chlorosis and necrosis; $4=$ intermediate, mycelium and conidia barely detectable; 5 to $6=$ moderately susceptible, small to moderate-sized lesions; and 7 to $9=$ susceptible, increasing amounts of mycelium and conidia production, up to a completely compatible reaction.

Fungicide sensitivity. The cultivar Chancellor was treated with $26 \mathrm{~g}$ of a.i. triadimenol per $100 \mathrm{~kg}$ of seed (Baytan 30 $2.65 \mathrm{~F}$, Bayer). Seed were planted in plastic pots and grown in a $17^{\circ} \mathrm{C}$ chamber with $12 \mathrm{~h}$ of light in a 24-h period. Two weeks later, 4 detached leaves of the Baytantreated plants were placed on sterile $50 \mathrm{mg} /$ liter benzimidazole-amended $0.5 \%$ water agar in 60 - by $15-\mathrm{mm}$ petri plates. The isolates were transferred to the treated plants using a paintbrush. Leaves were rated 2 weeks later using the scale modified by Leath (13) described above.

Data analysis. A chi-square statistical test was used to compare the actual and expected values of pairs of virulence genes based on independent assortment. The data for 1993 and 1994 were combined for analysis in order to have the minimum cell number of 5 in the 2 by 2 contingency tables. If an expected value was less than 5 , the chi-square was not interpreted. All pairwise combinations were tested for the 15 genes listed in Table 1.

Nei's (19) standard genetic distance measures similarity of gene frequencies between alleles at a number of genetic loci in the respective populations. Phenograms based on Nei's standard genetic distance were computed from the virulence gene frequencies from each state by the unweighted pair-group method to display relationships. Only those states with at least 5 isolates per state where included in this analysis. Nei's standard genetic distance (D) is given by the equation $\mathrm{D}=$ $-1 n \mathrm{I}$, in which $\mathrm{I}=\left(\Sigma \mathrm{i}\left|\mathrm{x}_{\mathrm{i}} \mathrm{y}_{\mathrm{i}}\right| / \sqrt{ } \Sigma_{\mathrm{i}} \mathrm{x}^{2}{ }_{\mathrm{i}} \mathrm{y}^{2}{ }_{\mathrm{i}}\right)$ where $\mathrm{x}_{\mathrm{i}}$ and $\mathrm{y}_{\mathrm{i}}$ are the frequencies of allele
$\mathrm{A}_{\mathrm{i}}$ in populations $\mathrm{X}$ and $\mathrm{Y} . \mathrm{I}=1$ when two populations have identical allele frequencies over all loci that are tested, and $\mathrm{I}=0$ when the two populations share no alleles. When $\mathrm{I}=0$, D is undefined.

\section{RESULTS}

A total of 256 isolates and 318 isolates were recovered from perithecia in 1993 and 1994, respectively. Isolates were collected from 59 cultivars from breeding nurseries as well as commercial fields. Of the isolates characterized, $40 \%$ were from the cultivars Becker, Cardinal, Coker 9835 ,

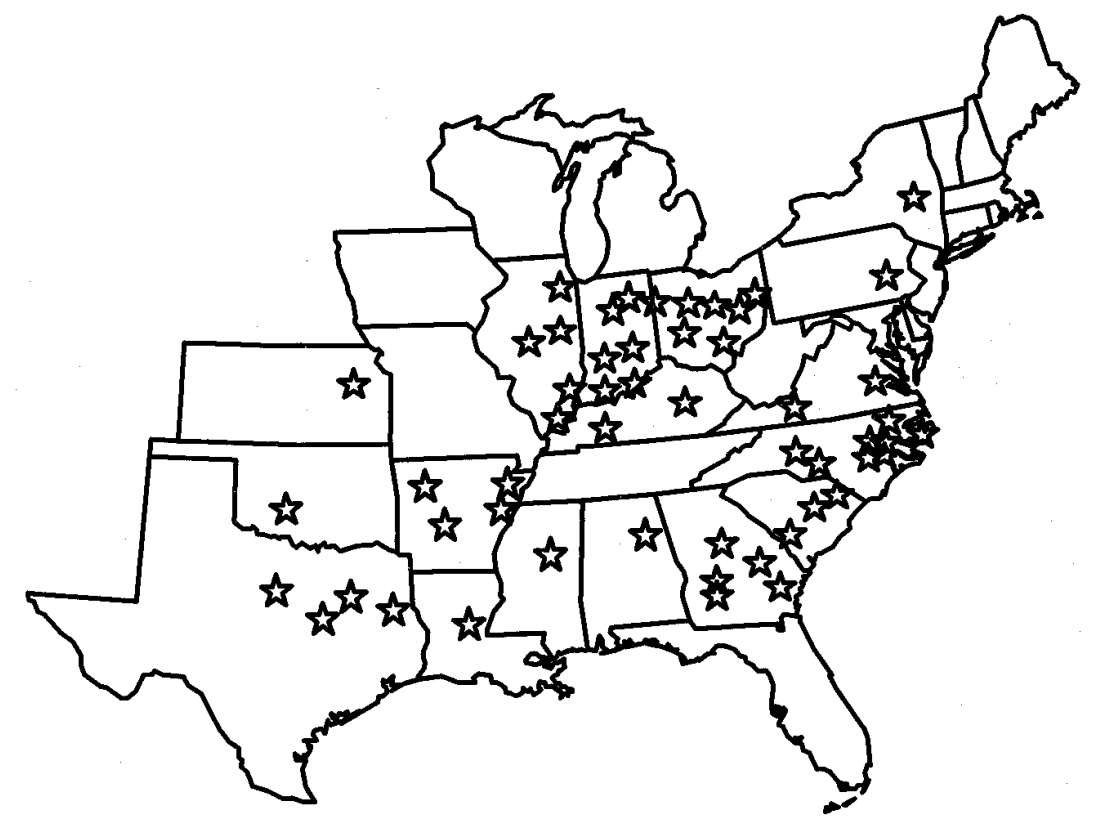

Fig. 1. Origin of the Blumeria graminis f. sp. tritici perithecia samples collected in 1993 and 1994 from the eastern United States.
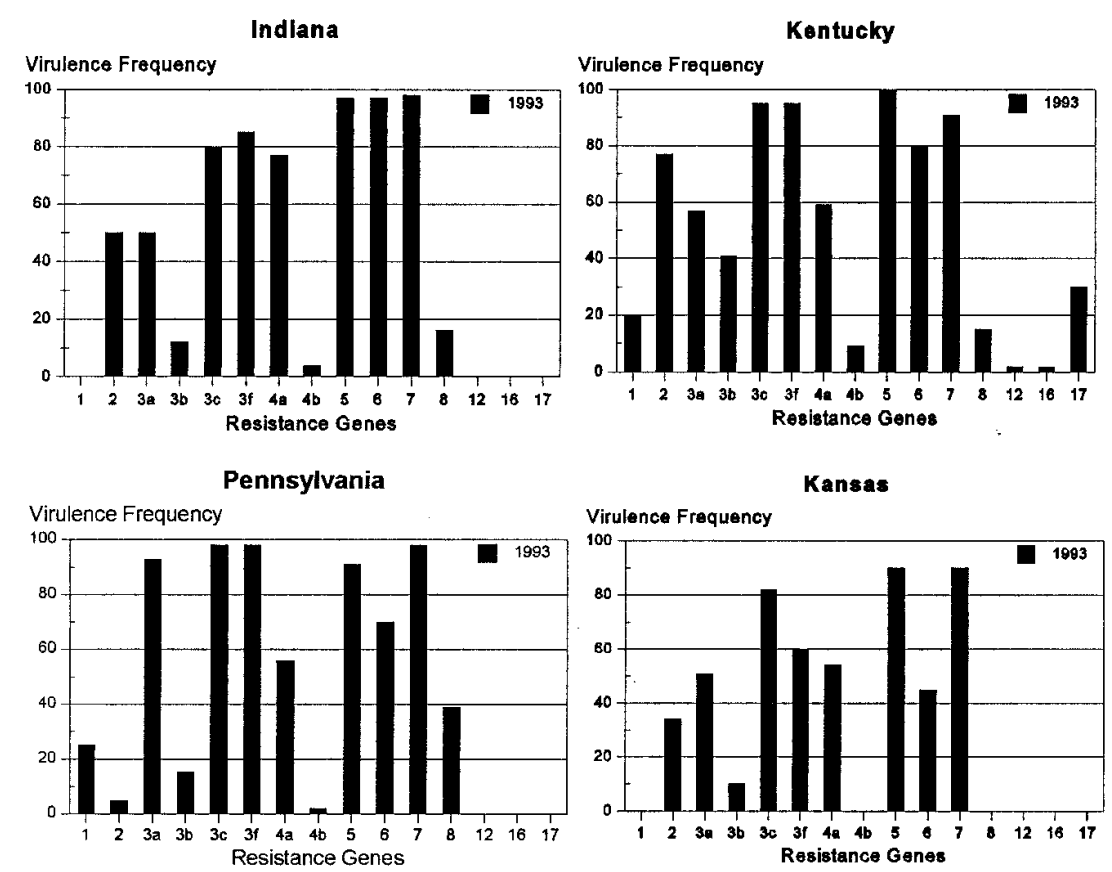

Fig. 2. Virulence frequencies in ascospore-derived isolates of Blumeria graminis f. sp. tritici from Indiana, Kentucky, Pennsylvania, and Kansas in 1993. reactions ranged from 0 to 9 . In some cases isolates produced both resistant (0 to 3 ) and intermediate (4 to 5) reactions on the same differential host, and it was not possible to clearly characterize the isolates. Such inconsistencies in the differential test were treated as missing data for a particular gene. Seed shortages also resulted in missing data for the resistance gene $p m 5$.

Virulence to Pm2, Pm3a, Pm3b, Pm3c, $P m 3 f, P m 4 a$, pm5, Pm6, and $P m 7$ were ana, Kansas, Kentucky, North Carolina,
Chancellor, and Saluda. Infection type identified in isolates from Georgia, Indi- 
Ohio, Pennsylvania, and Texas (Figs. 2 and $3)$. Virulence gene frequencies remained similar over 1993 and 1994 for the majority of the genes surveyed; however, there appeared to be a general increase in the frequency of isolates with virulence to $P m 4 b$ and Pm17 (Fig. 3). In Georgia and Texas, there was an increase in frequency of isolates with virulence to $\mathrm{Pm} 3 a$, whereas this virulence declined in Ohio from 1993 to 1994. Virulence to Pm12 and Pm16 was detected only in Kentucky and North Carolina.

The data for both years of the study were combined, and isolates were given a 15-digit number made up of zeros and ones which corresponded to the virulence response to each of the 15 resistance genes. Avirulent responses were coded 0 (IT 0 to 3 ), and virulent responses were coded 1 (IT 4 to 9 ), with the break occurring at IT 4 when sporulation is first observed. In order to obtain useful information from the sorting, the missing data were characterized as avirulent. Isolates with identical virulence/avirulence codes were sorted together to determine the racial composition of the population (Table 2). In the combined populations, 206 races were detected; of these, 121 races occurred only once in the total population. Table 2 lists races which comprised a total of $43 \%$ of the population, derived from 14 states and 46 cultivars. Most of the races were virulent to Pm3a, Pm3c, Pm3f, pm5, Pm6, and $P m 7$. Isolates carried from 2 to 9 and 2 to 11 virulence genes in 1993 and 1994, respectively (Fig. 4). During both years, 27 to $32 \%$ of the isolates contained 7 virulence genes per isolate. Isolates which carried 8 and 9 virulence genes were more prevalent in 1994 than 1993.

Table 2. Prevalent races of Blumeria graminis f. sp. tritici collected in 1993 and $1994^{\mathrm{z}}$

\begin{tabular}{|c|c|}
\hline Ineffective / effective resistance genes & Frequency $(\%)$ \\
\hline $3 \mathrm{c}, 3 \mathrm{f}, 7 / 1,2,3 \mathrm{a}, 3 \mathrm{~b}, 4 \mathrm{a}, 4 \mathrm{~b}, 6,8,12,16,17$ & 1.6 \\
\hline $3 \mathrm{c}, 3 \mathrm{f}, 6,7 / 1,2,3 \mathrm{a}, 3 \mathrm{~b}, 4 \mathrm{a}, 4 \mathrm{~b}, 8,12,16,17$ & 1.6 \\
\hline $3 \mathrm{a}, 3 \mathrm{c}, 3 \mathrm{f}, 6,7 / 1,2,3 \mathrm{~b}, 4 \mathrm{a}, 4 \mathrm{~b}, 8,12,16,17$ & 4.0 \\
\hline $1,3 \mathrm{a}, 3 \mathrm{c}, 3 \mathrm{f}, 6,7 / 2,3 \mathrm{~b}, 4 \mathrm{a}, 4 \mathrm{~b}, 8,12,16,17$ & 2.8 \\
\hline $2,3 \mathrm{a}, 3 \mathrm{c}, 3 \mathrm{f}, 6,7 / 1,3 \mathrm{~b}, 4 \mathrm{a}, 4 \mathrm{~b}, 8,12,16,17$ & 4.2 \\
\hline $2,3 \mathrm{c}, 3 \mathrm{f}, 4 \mathrm{a}, 6,7 / 1,3 \mathrm{a}, 3 \mathrm{~b}, 4 \mathrm{~b}, 8,12,16,17$ & 1.2 \\
\hline $3 \mathrm{a}, 3 \mathrm{c}, 3 \mathrm{f}, 4 \mathrm{a}, 6,7 / 1,2,3 \mathrm{~b}, 4 \mathrm{~b}, 8,12,16,17$ & 7.0 \\
\hline $1,2,3 a, 3 c, 3 f, 6,7 / 3 b, 4 a, 4 b, 8,12,16,17$ & 1.4 \\
\hline $1,3 \mathrm{a}, 3 \mathrm{c}, 3 \mathrm{f}, 6,7,17 / 2,3 \mathrm{~b}, 4 \mathrm{a}, 4 \mathrm{~b}, 8,12,16$ & 1.4 \\
\hline $2,3 \mathrm{a}, 3 \mathrm{c}, 3 \mathrm{f}, 4 \mathrm{a}, 6,7 / 1,3 \mathrm{~b}, 4 \mathrm{~b}, 8,12,16,17$ & 5.6 \\
\hline $3 a, 3 b, 3 c, 3 f, 4 a, 6,7 / 1,2,4 b, 8,12,16,17$ & 1.7 \\
\hline $3 a, 3 c, 3 f, 4 a, 6,7,8 / 1,2,3 b, 4 b, 12,16,17$ & 1.6 \\
\hline $3 a, 3 c, 3 f, 4 a, 6,7,17 / 1,2,3 b, 4 b, 8,12,16$ & 1.6 \\
\hline 3a, 3c, 3f, 4a, 4b, 6, $7 /$ 1, 2, 3b, 8, 12, 16, 17 & 1.2 \\
\hline $2,3 a, 3 b, 3 c, 3 f, 6,7 / 1,4 a, 4 b, 8,12,16,17$ & 2.8 \\
\hline $2,3 \mathrm{a}, 3 \mathrm{c}, 3 \mathrm{f}, 4 \mathrm{a}, 6,7,17 / 1,3 \mathrm{~b}, 4 \mathrm{~b}, 8,12,16$ & 1.7 \\
\hline $2,3 \mathrm{a}, 3 \mathrm{~b}, 3 \mathrm{c}, 3 \mathrm{f}, 4 \mathrm{a}, 6,7,17 / 1,4 \mathrm{~b}, 8,12,16$ & 1.7 \\
\hline
\end{tabular}

${ }^{\mathrm{z}}$ pm 5 was omitted from this analysis due to missing data.
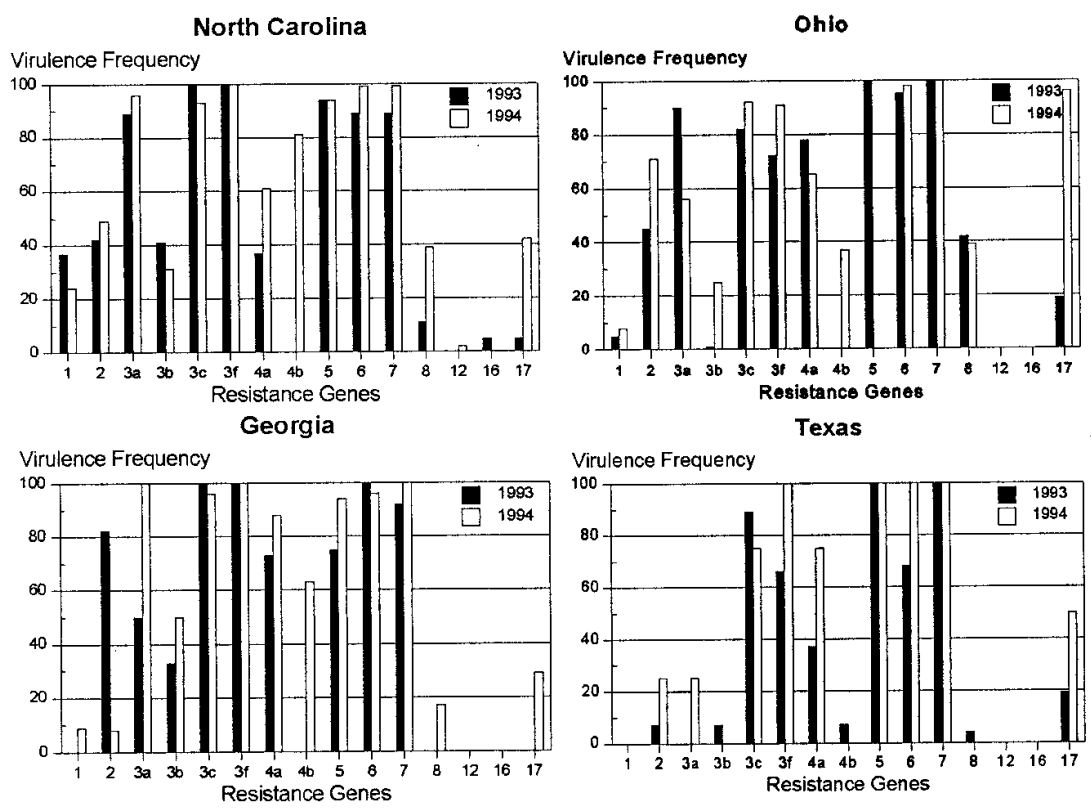

Fig. 3. Virulence frequencies in ascospore-derived isolates of Blumeria graminis f. sp. tritici from North Carolina, Ohio, Georgia, and Texas in 1993 and 1994.
The results of the chi-square test indicated that approximately half of the gene pair combinations sorted independently and, of the remainder, the observed frequency of virulence gene pair combinations was greater than expected for all gene pairs except the Pml-Pm4a combination (Table 3). The alleles at the Pm3 and Pm4 loci were associated.

Phenograms based on Nei's standard genetic distance indicated no strong trend in regional clustering (Figs. 5 and 6). States from the south, northeast, and south-central regions were not consistently paired together.

Fungicide sensitivity. All isolates transferred to triadimenol-treated Chancellor plants were sensitive to the fungicide as indicated by an infection type rating between 1 and 3 .

\section{DISCUSSION}

This study detected virulence to $P m 2$, Pm3a, Pm3b, Pm3c, Pm3f, Pm4a, pm5, $P m 6$, and $P m 7$ in the eastern United States. Previous surveys in Pennsylvania and New York reported low levels of virulence to Pm3a. Since then, the number of isolates with virulence to this resistance gene has increased across the northeast. This study confirmed the infrequency of virulence to $P m 1$ and $P m 3 b$ found recently by Persaud et al. in Ohio (21), and also detected a virulence frequency less than $10 \%$ to $P m 4 b$. A large increase in virulence to Pml7 was discovered in Ohio in 1994. Leath's survey of the eastern United States in 1991 did not detect virulence to Pm17 (11). The decline in effectiveness of $P m 1$, $P m 3 b, P m 4 a$, and $P m 8$ is already occurring in different areas of the southeast. Although $P m 4 b$ and $P m 17$ remain effective in the field, if they are placed in cultivars grown on a large area they may decline in effectiveness as the level of virulence increases in the powdery mildew population. Genes Pm12 and Pm16 are highly effective; however, their use in breeding lines in the United States is limited. This may be due in part to intellectual property rights issues.

Virulence frequencies are highly influenced by the resistance genes carried by

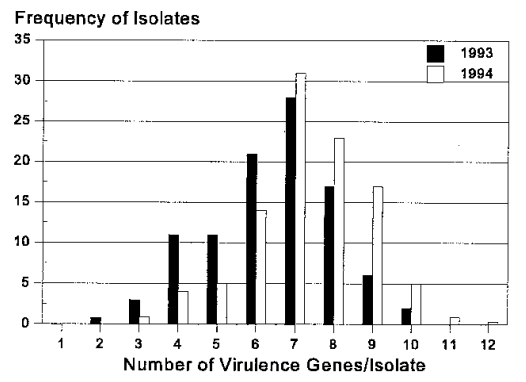

Fig. 4. Number of virulence genes per isolate in ascospore-derived isolates of Blumeria graminis f. sp. tritici in the 1993 and 1994 populations. 
cultivars grown in a particular area. Genes Pm2, Pm3a, pm5, Pm6 and recently $P m 8$ have been individually released into commercial cultivars $(1,13,21)$. Cultivars containing the pairs $P m 2+P m 6$ and $p m 5+$ Pm6 have also been released $(1,13)$. Pm17 has been released in hard wheat cultivars, and it is being used in breeding programs in the eastern United States. Host-driven selection may account for the presence of high levels of virulence to some of these genes, but this does not explain the high levels of virulence to $P m 3 c, P m 3 f$, and $P m 7$. Pm $3 c$ and $P m 3 f$ were shown to be associated with other alleles at the $P m 3$ locus. $P m 7$ has not been released in this country, but there may be a selective advantage to the fungus in carrying virulence to this gene, or it may be present in uncharacterized cultivars.

Current knowledge of deployed resistance genes is incomplete and cannot fully explain the virulence frequencies detected in this study. It appears that this pathogen is able to carry a large number of virulence genes without serious impact to general fitness. This study detected greater levels of racial diversity and average number of virulence genes per isolate than previous surveys $(18,22)$. This latter result may be due in part to the classification of intermediate types as virulent. Persaud et al. also detected 7 virulence genes per isolate when they tested isolates for virulence to 11 resistance genes (21). The increase in number of virulence genes per isolate from 1993 to 1994 could be attributed to a difference in cultivars sampled from different states. The number of isolates decreased as the number of virulence genes per isolate approached either extreme (Fig. 4). Isolates from Texas, Oklahoma, and Kansas carried an average of 6 virulence genes per isolate, whereas all other states varied from 7 to 8 virulence genes per isolate. Leath reported lower disease severities and lower diversity in virulence in Louisiana and Texas than the other southeastern states. This may account for the decreased complexity and lower virulence frequencies found in this region (11).

There have been several reports of associations between virulence genes in the wheat powdery mildew fungus $(18,21,22)$. Resistance genes $\mathrm{Pm} 8$ and $\mathrm{Pm} 17$ were derived from wheat-rye translocations, and are associated with chromosomes 1BL/ $1 \mathrm{RS}$ and $1 \mathrm{AL} / 1 \mathrm{RS}$, respectively $(6,8)$. It is possible that the associated virulence to these 2 genes from rye is due to their common origin. These 2 genes have not been released together in soft winter wheat lines. The association of virulence genes $p 4 a$ and $p 8$ was reported by Namuco (18). Our results confirmed the association of virulence to $P m 3 c$ and $P m 3 f$ (formerly designated Michigan Amber) detected by Royer (22). We were not able to detect associations between $P m 2$ and pm5 or $P m 3 c$ and $P m 4 a$ as reported by Royer. The association between putative alleles at the Pm3 locus suggests either a series of closely linked genes in the host rather than alleles at one locus, or that different virulence genes correspond to alleles from a single locus in the host. These gene combinations may be due to strong associations in the pathogen, due to a selective advantage in carrying virulence to these gene pairs, or an artifact of sampling ascospore progeny. It is advisable for breeders not to rely solely on combinations of the gene pairs listed in Table 3 .

Table 3. Observed numbers from 2 by 2 contingency table of chi-square test for independence of virulence genes using combined data from 1993 and 1994

\begin{tabular}{|c|c|c|c|c|c|c|}
\hline \multicolumn{2}{|c|}{ Virulence genes } & \multicolumn{4}{|c|}{ Virulence pairs } & \multirow[b]{2}{*}{ Chi-square statistic } \\
\hline $\mathbf{A}$ & B & $\mathbf{A}+\mathbf{B}$ & $A, \operatorname{not} B$ & $B, \operatorname{not} A$ & Neither & \\
\hline$p 1$ & $p 3 a^{z}$ & 85 & 6 & 301 & 115 & 18.2 \\
\hline pl & $p 4 a$ & 23 & 65 & 260 & 143 & 43.6 \\
\hline$p 2$ & $p 3 a$ & 206 & 43 & 180 & 75 & 10.4 \\
\hline$p 2$ & $p 3 b$ & 69 & 156 & 49 & 185 & 5.7 \\
\hline p2 & $p 3 f$ & 80 & 143 & 57 & 163 & 4.5 \\
\hline p2 & p17 & 240 & 11 & 240 & 24 & 5.1 \\
\hline$p 3 a$ & $p 3 b$ & 111 & 261 & 16 & 104 & 13.0 \\
\hline$p 3 a$ & $p 3 c$ & 404 & 15 & 97 & 21 & 30.0 \\
\hline$p 3 a$ & $p 3 f$ & 422 & 6 & 93 & 33 & 91.4 \\
\hline$p 3 b$ & $p 3 c$ & 124 & 2 & 322 & 34 & 8.6 \\
\hline$p 3 b$ & $p 3 f$ & 82 & 40 & 193 & 157 & 11.3 \\
\hline$p 3 b$ & $p 4 a$ & 46 & 68 & 82 & 225 & 5.4 \\
\hline$p 3 b$ & $p 17$ & 126 & 1 & 336 & 37 & 7.3 \\
\hline$p 3 c$ & $p 3 f$ & 485 & 25 & 25 & 12 & 11.25 \\
\hline$p 4 a$ & $p 4 b$ & 48 & 222 & 17 & 183 & 8.3 \\
\hline$p 4 a$ & P8 & 62 & 222 & 26 & 170 & 5.7 \\
\hline$p 4 b$ & p17 & 31 & 24 & 87 & 277 & 24.90 \\
\hline$p 8$ & p17 & 32 & 41 & 89 & 257 & 9.7 \\
\hline
\end{tabular}

${ }^{y}$ Significant at the 0.05 level at $X^{2}>3.34$.

z 18 of 45 gene pairs presented.

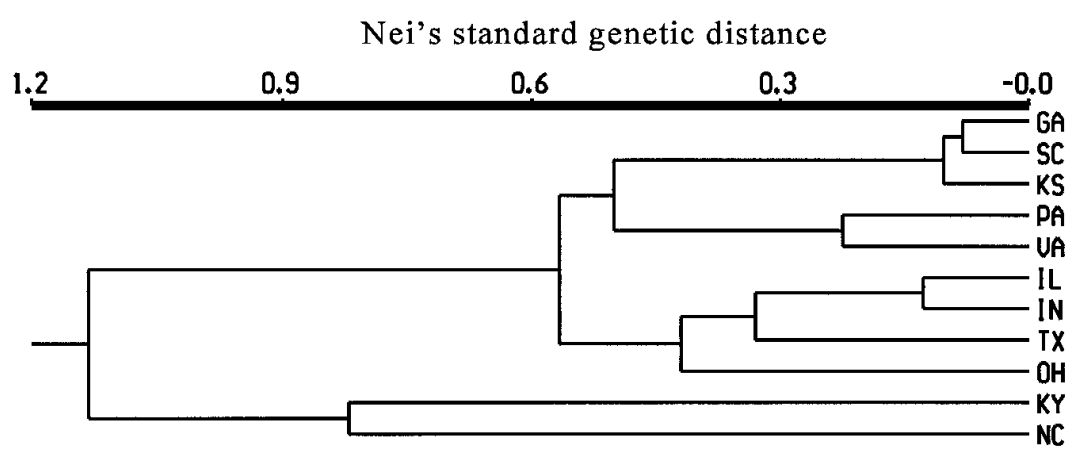

Fig. 5. Phenogram of similarities between states (1993) based upon virulence frequencies in ascosporederived isolates of Blumeria graminis f. sp. tritici as determined by Nei's standard genetic distance.

\section{Nei's standard genetic distance}

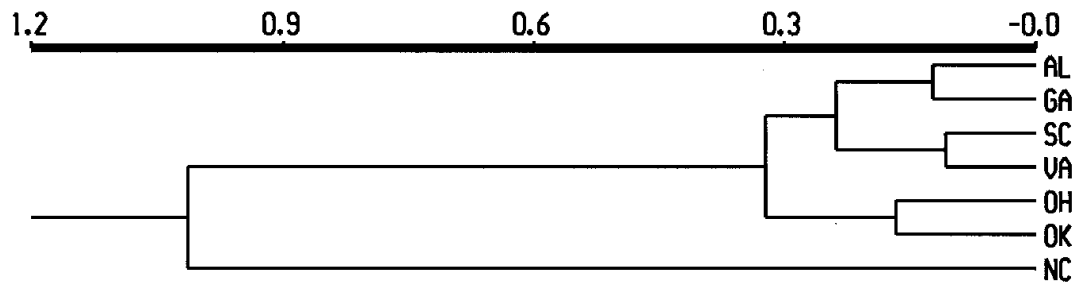

Fig. 6. Phenogram of similarities between states (1994) based upon virulence frequencies in ascosporederived isolates of Blumeria graminis f. sp. tritici as determined by Nei's standard genetic distance. 
the diversity identified in the states. In addition, isolates derived from the perithecia have not undergone direct selection. Several studies have shown that sampling from breeding nurseries may result in the detection of more complex and diverse isolates $(15,18)$, and the samples received in the study were derived from both nurseries and commercial fields. More information regarding resistance genes present in host lines is needed to further characterize the relationship between host resistance and pathogen virulence.

\section{ACKNOWLEDGMENTS}

We thank J. E. Bailey, M. L. Carson, C. E. Main, and J. Paul Murphy for their critical review of the manuscript; and Alan Schepps, Ainong Shi, Scott Walker, and Lynda Whitcher for technical assistance in conducting these studies.

\section{LITERATURE CITED}

1. Bennett, F. G. A. 1984. Resistance to powdery mildew in wheat: a review of its use in agriculture and breeding programmes. Plant $\mathrm{Pa}-$ thol. 33:279-300.

2. Christ, B. J., and Frank, J. A. 1989. Influence of foliar fungicides and seed treatments on powdery mildew, Septoria, and leaf rust epidemics on winter wheat. Plant Dis. 73:148-150.

3. Ecker, U., and K. A. Lein. 1994. Use and significance of resistance genes against powdery mildew (Erysiphe graminis) in German wheat varieties in the years 1980 to 1993 . Pflanzenschutz-Nach. 47:91-128.

4. Everts, K. L., and Leath, S. 1993. Effect of triadimenol seed treatment and timing of foliar fungicide applications on onset and extent of powdery mildew and leaf rust epidemics. Phytopathology 83:557-562.
5. Frank, J. A., and Ayers, J. E. Effect of triadimenol seed treatment on powdery mildew epidemics on winter wheat. Phytopathology 76:254-257.

6. Friebe, B., Heun, M., and Bushuk, W. 1989. Cytological characterization, powdery mildew resistance and storage protein composition of tetraploid and hexaploid 1BL/1RS wheat-rye translocation lines. Theor. Appl. Genet. 78:425-432.

7. Heun, M. 1987. Virulence frequencies influenced by host resistance in the host-pathogen system wheat-powdery mildew. J. Phytopathol. 118:363-366.

8. Heun, M. Friebe, B., and Bushuk, W. Chromosomal location of the powdery mildew resistance gene of Amigo wheat. Phytopathology 80:1129-1133.

9. Jevtic, R., Pribakovic, M., Stojanovic, S., and Leath, S. 1991. Screening the virulence of Erysiphe graminis DC. Ex Merat f. sp. tritici em. Marchal in mobile nurseries. Plant Prot. 42:21-31.

10. Johnson, J. W., Baenziger, P. S., Yamazaki, W. T., and Smith, R. T. 1979. Effects of powdery mildew on yield and quality of isogenic lines of 'Chancellor' wheat. Crop Sci. 19:349-352.

11. Leath, S. 1991. Wheat powdery mildew in the USA: Status of pathogen virulence and host resistance Pages 23-32 in: Integrated Control of Cereal Mildews: Virulence Patterns and Their Change. J. Helms Jorgensen, ed. Riso National Laboratory, Roskilde, Denmark.

12. Leath, S., and Bowen, K. L. 1989. Effects of powdery mildew triadimenol seed treatment, and triadimefon foliar sprays on yield on winter wheat in North Carolina. Phytopathology 79:152-155.

13. Leath, S., and Heun, M. 1990. Identification of powdery mildew resistance genes in cultivars of soft red winter wheat. Plant Dis. 74:747-752.
14. Leath, S., and Murphy, J. P. 1985. Virulence genes of the wheat powdery mildew fungus, Erysiphe graminis f. sp. tritici in North Carolina. (Note.) Plant Dis. 69:905.

15. Leonard, K. Roelfs, A. P., and Long, D. L. 1992. Diversity of virulence within and among populations of Puccinia recondita $\mathrm{f}$. sp. tritici in different areas of the United States. Plant Dis. 76:500-504.

16. Limpert, E., Felsenstein, F. G., and Andrivon, D. 1987. Analysis of virulence in populations of wheat powdery mildew in Europe. J. Phytopathol. 120:1-8.

17. Lipps, P. E., and Madden, L. V. 1989. Effect of fungicide application timing on control of powdery mildew and grain yield of winter wheat. Plant Dis. 73:991-994.

18. Namuco, L. O., Coffman, W. R., Bergstrom, G. C., and Sorrells, M. E. 1987. Virulence spectrum of the Erysiphe graminis f. sp. tritici population in New York. Plant Dis. 71:539-541.

19. Nei, M. 1972. Genetic distance between populations. Am. Nat. 106:283-292.

20. Persaud, R. R., and Lipps, P. E. 1995. Virulence genes and virulence gene frequencies of Blumeria graminis f. sp. tritici in Ohio. Plant Dis. 79:494-499.

21. Persaud, R. R., Lipps, P. E., and Campbell, K G. 1994. Identification of powdery mildew resistance genes in soft red winter wheat cultivars and Ohio breeding lines. Plant Dis. 78:1072-1075

22. Royer, M. H., Nelson, R. R., and MacKenzie, D. R. 1984. An evaluation of the independence of certain virulence genes of Erysiphe graminis f. sp. tritici. Phytopathology 74:1007-1010.

23. Zeller, F. J., Lutz, J., and Stephan, U. 1993. Chromosome location of genes for resistance to powdery mildew in common wheat (Triticum aestivum L.) 1. Mlk and other alleles at the Pm3 locus. Euphytica 68:223-229. 